\title{
Perspectives
}

\section{Krashen, a Victim of History}

\section{Garon Wheeler}

\section{Introduction}

A few years ago I submitted an article for publication in a well-known journal. In it, almost in passing, I mentioned Stephen Krashen. I do not even remember what I said about Krashen; I believe it had something to do with his ideas on the importance of reading, which was the topic of a keynote address I had once heard him give. I like Krashen, but I knew when I submitted the article that he was out of favor with the highest authorities in our field. I was hoping that the editors would not mind-but they did. I wish I had kept the letter they sent me; all I remember is that it contained a friendly, mild admonishment that Krashen was passé because his ideas were "unverifiable." They were, nevertheless, willing to publish the article, but on one condition: all references to Krashen had to be removed. Given a choice of defending the ideals of intellectual and academic freedom, or having my article published, I chose the latter. So after undergoing what could be termed a radical Krashenectomy, the article finally made its appearance.

\section{Krashen and His Theory}

Stephen Krashen has written more than 250 publications, including 10 books. He has won several awards for his writings and been invited to speak (more than 300 times by one count) at a great number of major conferences. For years he has been a professor of linguistics at the University of Southern California. Since Krashen first came to the public's attention in the 1970s, he has been the best-known figure in the field of language teaching with his theory of second-language acquisition. Let me take just a minute to review what that theory says. It consists of five hypotheses. The first claims that there is a distinction between learning and acquisition. Classrooms traditionally promote and test learning, whereas acquisition, which is what we can call "truly knowing a language," is gained only through meaningful communication. Another hypothesis is that there is a natural order of acquisition of grammatical structures. The third is his monitor hypothesis, which says that the learning system under the right conditions (mainly having enough time) "monitors" the output of the acquisition system. The degree to which a person uses the monitor is principally a function of personality type. The fourth, and doubtless the best-known hypothesis, regards the role of input. A 
learner progresses by receiving comprehensible input that is slightly beyond his or her current level of knowledge. The final hypothesis addresses the role of psychological factors. Low motivation, anxiety, and low self-esteem, for example, create a mental block, or what Krashen calls an affective filter, that hinders the comprehensible input essential to language acquisition.

Krashen's theory of second-language acquisition has been closely analyzed and heavily criticized, as happens to any conspicuous theory. These criticisms began a long time ago, almost as soon as his theory began to attract notice. The best summary of these criticisms is from his most persistent critic, McLaughlin (1987). Like many other researchers, he objects to the learning/acquisition distinction, saying that it is not well defined and that Krashen's claims based on it cannot be tested. He has similar complaints about comprehensible input and the Input Hypothesis. As for the Affective Filter Hypothesis: well, that's vague and not capable of predicting linguistic development. And so on: the Monitor doesn't work as Krashen claims, and the Natural Order Hypothesis is defective because of methodological considerations. In short, nothing works right in Krashen's theory, he says, and there are many examples of other researchers and writers who disagree with Krashen. Beyond these criticisms, moreover, Krashen's theory has aroused a hostility that is unusual and sometimes has the air of a personal attack. For example, in a TESOL Quarterly review of Krashen's (1985) book on the Input Hypothesis, one tenacious critic, Gregg (1986), compared Krashen's theory to a Monty Python routine (1985). In this review he used the words feeble, ignorance, vacuousness, intolerably sloppy, profound misunderstanding, and illegitimate when evaluating Krashen's claims. All these attacks, both professional and personal, have taken their toll over the years. Although Krashen remains popular among many, he has effectively been dismissed by the big names in the field. This idea has filtered down to the teaching level.

In a way, the hostility directed toward Krashen is not surprising. After all, it is only normal for whoever finds himself at the top to be the target of those below. And there is no question that Krashen was at the top of our field in the 1980s. In my opinion, however, the personal nature and the lack of collegiality of some of the attacks he has suffered through the years are remarkable and show that there is something deeper than the traditional challenges to the leader. I think that Krashen's fate was foretold from the beginning. His rise was not surprising, and the nastiness of his fall was inevitable. I believe that he was a victim of history.

\section{A Bit of History}

When we talk about the history of language study, there are two basic points to remember. Linguistics did not exist until the 1800s, and applied linguistics, meaning a concern with how languages are taught and learned, is even younger. The study of language throughout history usually has meant the 
study of grammar. Grammar was the basis of all knowledge. Mostly it meant asking how grammar could best be applied to the study of literature and religion and be used for effective speaking and writing. As far back as Aristotle, continuing with the modistae of the 12th to 13th centuries, the Arabic grammarians of the 8th to 11th centuries, and the rational grammar movement of the 1500 s to the 1700 s, we find attempts to explain language in terms of philosophy, which in those days was "science." In other words, language study was as scientific as possible. However, it largely depended on the individual interpretations and insights of scholars. This made language study a highly personalized field of study, and these inquiries had no effect on the teaching of languages in the West and the Arab world for 2,000 years. In fact, how to teach this all-important subject was rarely considered. It was not necessary really, because although teachers were respected, it was thought that anyone with an education was qualified to teach. Learning a language was a straightforward matter of receiving and practicing the information found in the textbooks while being guided by the teacher. Language teaching, as well as the application of the new language, was an art acquired by hard work; some teachers were simply more talented than others in this art.

Modern times in language study began in 1786 , for it was in that year that Sir William Jones delivered his famous speech in which he declared that Latin and Greek were related to Sanskrit, an Indian language (Robins, 1979). This startling (and scandalous) fact, coupled with a new interest in languages of East Asia and India due to increasing trade, created a sudden interest in the history of languages and the relationships among them. In the early 1800 s, Rask, Bopp, and Grimm founded historical linguistics, the first scientific branch of language study (Robins, 1979). This coincided with the beginnings of the Scientific Revolution, circa the 1820 s to 1840 s, which eventually led to the scientific method. Now here is an important point: The new industries and technology created a tremendous respect for the hard sciences; they also brought about an inferiority complex to the social, soft sciences of psychology, linguistics, and sociology: one that survives to this day. Ever afterward, the quest for respectability has had to be via science, and the harder the science the better. A good example of this is August Schleicher's biological approach to language in his book Darwinian Theory and Linguistics of 1863, in which he presented his view of languages as natural organisms with families and offspring, births and deaths (Robins, 1979). The identification with those sciences that had made such remarkable advances was complete with the work of the so-called neogrammarians of the 1870s, who spoke of laws governing sound change that had no exceptions. Without such strong statements, one of them said, "one is basically stating that the object of one's research, language, is not amenable to scientific recognition" (Leskien, 
quoted in Robins, 1979, p. 183). The success of the neogrammarians inspired a reform movement in language teaching in the late 1800s. After remaining stagnant for two millennia, language teaching was clearly not meeting the needs of an industrial society. With Henry Sweet as its intellectual leader, this reform movement used the new science of phonetics as the foundation of a new approach to teaching, one that had the spoken language as its goal (Howatt, 1984, chap. 13). On the other hand, spurred mostly by an increase in immigration and the need to teach beginning language to a largely adult and less educated population, a different way of reforming language teaching in the late 1800 s was seen in the rise of what are still known as "natural" methods of langauge teaching. This includes the work of Maximilian Berlitz, whose method is thriving today (Howatt, 1984, chap. 14).

Now, at last, we can begin to return to Krashen. Today the phrase natural approach is commonly associated with Krashen. It is a mistake, however, to assume that it is a recent innovation or that Krashen and his partner Tracy Terrell can be given any credit for it. What any methods based on a natural approach have in common, whether today or in the late 1800 s, is the belief that "Learning how to speak a language ... is not a rational process which can be organized in a step-by-step manner following graded syllabuses ... It is an intuitive process for which human beings have a natural capacity that can be awakened provided only that the proper conditions exist" (Howatt, 1984 , p. 192). All that natural methods require are "someone to talk to, something to talk about, and a desire to understand and make yourself understood" (p. 192). Does this sound familiar? Compare this to Krashen's meaningful communication, his stress on psychological factors, and anti-formal-grammar bias.

The roots of these methods lie in what? Intuition? Common sense? Howatt (1984) states that they owe only a little to psychology, and almost nothing to linguistics. He calls them the "'alter ego' or 'mirror image' of the rational teaching methods put forward by the Reform Movement" (p. 197). Just as today, these methods received a lot of attention but were never widely accepted in schools. The main criticism was that their emphasis on communication trivialized language instruction. This referred to the view that the teaching of conversation was inferior to the classical, standard study of grammar and literature.

\section{The Problem with Krashen}

Now back to the present. After reaching the summit of our profession, Krashen has been exiled to the outer regions. So what is the problem with Krashen?

We see that Krashen is in some ways a recycling of the natural approaches of the 19th century. They did not gain universal acceptance then because of the "trivialization" factor. This was essentially the 19th-century way of 
saying that they were not scientific enough. A century later, and Krashen is criticized for the same thing. "Not verifiable" equals not scientific enough. In the 2003 this means it is not to be taken seriously: it is too trivial. It offends the dignity of the field.

The leaders in the field of applied linguistics have usually been scientists rather than artists, giving a definite bias in outlook. Krashen is an artist. Although he can claim credentials as a "hard scientist" because of his background in neurolinguistics, his theory of second-language acquisition is more representative of the intuition and personal interpretation of pre-scientific times. Linguistics has gone a middle route between art and science, recognizing that not everything can be quantified, and that speculation about what is happening in the brain is inevitable, but language teaching, a softer and hence more vulnerable science, has stayed with the notion of unmeasurable $=$ unverifiable $=$ of no value.

A more formal way of evaluating Krashen's theory is provided by Stern (1983) among others. There are six criteria for deciding whether a theory is a good one or a bad one. Krashen's theory scores high on the criterion of simplicity and clarity. It also satisfies well the requirement of comprehensiveness, because it describes the language learning of anyone in any situation. Beyond these two, though, trouble looms. Is the theory useful and applicable? Many teachers would say Yes, emphatically so; many researchers would strongly disagree. As for the criterion of explicitness, Krashen has been thoroughly criticized in this regard. The theory, according to some, is so vague that it really says nothing. Similarly, its vagueness enables one to find any number of irregularities in violation of the fifth requirement of coherence and consistency. The final criterion is that of explanatory power and verifiability, and here is the biggest problem. "The value of a scientific theory ... normally lies in its explanatory power, its capacity to predict, and in the direction it gives to empirical research... In short, a good theory stimulates research" (Stern, 1983, p. 29). Krashen's ideas are "terminal" in the sense that there is really nowhere to go from there. How can we investigate the monitor? How can we truly determine if learning can transform into acquisition? What do we do with the Input Hypothesis? This is understandably upsetting to researchers. What do you do if you are an expert? As in any field, your livelihood and reputation depend on moving forward. The time-honored way of accomplishing this is by attacking current theories and whoever is at the top. Krashen's theory is extremely vulnerable on grounds of scientific inadequacy. The obvious result of this is a concerted attack on Krashen and his theory and an all-out attempt to bury it.

Resilience of The Theory

And yet neither the 19th century natural approaches nor Krashen will go away because of a paradox of conflicting interests: Although applied lin- 
guists want data and science, teachers want things clear and useful. Therefore, in spite of repeated attempts to marginalize Krashen, he continues to enjoy remarkable popularity. $\mathrm{He}$ is accessible. He is easy to understand. $\mathrm{He}$ appeals to common sense. He makes you feel good: that you can accomplish something, not like experts who can at times make you feel inferior, inadequate, and that you cannot begin to penetrate the mysteries of language acquisition. Call him "the people's expert." He provides a satisfactory explanation and guidelines for many teachers; do they really want to know or hear any more?

Going back to the original and most damning accusation against Krashen: his theory is unverifiable. This is absolutely true, but the term is used so pejoratively that it needs to be reexamined. From the viewpoint of a scientist, the theory is indeed unacceptable. But teachers are not scientists. Why is "unverifiable" so bad? The philosopher and scholar Polanyi (1957) spoke of "personal knowledge." In brief, he said not to let science blind you to what experience tells you. I take this to mean in our case that if you can benefit from the ideas of Krashen, good for you, and don't worry about what is supposedly the correct view. Otherwise you find yourself in the absurd and untenable position of being told to give back what you have gained from Krashen simply because it is not possible to benefit from him. Chomsky has said that you cannot know exactly what goes on inside the head, so accept a theory for what it predicts, and don't worry about how it works. Make the necessary changes as circumstances dictate. Replace the theory if something better comes along. This is in the same spirit as what Thomas Kühn said in his famous book The Structure of Scientific Revolutions, in which he said that a theory stands until a more responsive and productive one comes along. Kühn is often cited by linguists because he is so scientific. He wrote for the hard sciences, but the social sciences have taken him to heart as well in their crusade for respectability. Language pedagogy seems especially set on following Kühn's dictum. Seen in this light, when we ask whether Krashen's theory was the kind of paradigm shift that Kühn spoke about, the answer is clear. Krashen was not scientific enough even to qualify for consideration. This explains the indignant reaction of many researchers; here was someone not playing by the rules who came along and disrupted the game.

In recent decades there has been talk of "anti-intellectualism" in the United States, especially since the publication of Hofstadter's (1963) classic book Anti-intellectualism in American Life. The argument is that the democratic and anti-aristocratic legacy of the US has long led Americans to look on the educated with suspicion and to challenge their intellectual authority. Some see the appeal of Krashen as an excellent example of this, particularly because, as Krashen (1985) himself says, his theory has had more success with American teachers outside the university level. Presumably they have 
less education and are more prone to this phenomenon of anti-intellectualism. It is appropriate that even this negative term has a more scientific ring to it: the 19th-century term trivialization sounds trivial; anti-intellectual sounds deep and important. Krashen's nemesis Gregg (1986) makes two telling comments in this regard in his review of the Input Hypothesis: "it is very disturbing to see how well-received the theory seems to be." Then he states, "For the fundamental message of Krashen's theory is that you do not have to know very much to be a good language teacher" (p. 121). In these few words I think we have reached the core of the anti-Krashen argument. Acceptance of Krashen throws a glaring light on that stubborn inferiority complex. Krashen's theory threatens to expose, it is feared, that science and language teaching do not always mix. It shifts the balance away from science and technology back toward teaching as an art. It strengthens that age-old, exasperating belief that anyone with an education can teach.

\section{Conclusions}

So what are the lessons of the story? There are several. First, if Krashen's theory was really nothing but recycled ideas, is it fair to hail him as a guru? On the other hand, is it fair to ignore what he has to say if the old ideas still have appeal? Genuine guru or not, it should be up to the individual to decide the fate of Krashen. Second, we see that Krashen was doomed historically from the beginning. Although he and his followers have cited and produced many studies, there always seems to be room for disagreement based on methodology, definitions, or something else. It is clear that there is no getting around the requirement that to make permanent changes in education, one must use science. Krashen's failure to adhere to this exposes the gap that remains in teaching between art and science. The truly important question is whether this gap poses a problem or not. The case of Krashen indicates that it does, because we have seen opposing sides who, figuratively at least, keep screaming at each other, "You just don't understand!"

The Krashen affair shows the usefulness of an awareness of the history of our field. It is always an intriguing question whether the principal players in an academic drama would have behaved differently if they had had more of a historical perspective. But the question is equally suited to us as the spectators. I would hope that a more developed sense of history would allow us to see the futility of such an argument as the one we have with pro- and anti-Krashen. Trying to reach a definitive answer to whether Krashen is right or wrong is the same as attempting to decide whether art or science is superior in the teaching of languages. And I certainly am not foolhardy enough to respond. I leave it to you to decide whether you care to continue a debate that has been ongoing for centuries. 


\section{The Author}

Garon Wheeler has taught English and linguistics in the US, Italy, and the Middle East. He is the former ESL/EFL director at Huron University in the US and the University of Sharjah in the United Arab Emirates. He now works for the Scholarship Coordination Office in Abu Dhabi in the UAE. His principal academic interest is the history of linguistics and language teaching, especially the Port-Royal Grammar. He welcomes comments at garonw@hotmail.com.

\section{References}

Gregg, K. (1986). Review of The input hypothesis: Issues and implications by S. Krashen. TESOL Quarterly, 20, 116-122.

Hofstadter, R. (1963). Anti-intellectualism in American life. New York: Alfred A. Knopf. Howatt, A. (1984). A history of English language teaching. Oxford, uk: Oxford University Press. Krashen, S. (1985). The input hypothesis: Issues and implications. London: Longman.

Kühn, T. (1962). The structure of scientific revolutions. Chicago: University of Chicago Press. McLaughlin, B. (1987). Theories of second-language learning. London: Edward Arnold.

Polanyi, M. (1957). Personal knowledge. Chicago, IL: University of Chicago Press.

Robins, R.H. (1979). A short history of linguistics (2nd ed.). London: Longman.

Stern, H.H. (1983). Fundamental concepts of language teaching. Oxford, UK: Oxford University Press. 